IRSTI 68.35 .31

\author{
${ }^{1 *}$ B.N. Doszhanova, ${ }^{2}$ S.V. Didorenko, ${ }^{1}$ A.K. Zatybekov, \\ ${ }^{1}$ Y.K. Turuspekov, ${ }^{1}$ S.I. Abugalieva \\ ${ }^{1}$ Institute of Plant Biology and Biotechnology, Almaty, Kazakhstan \\ ${ }^{2}$ Kazakh Research Institute of Agriculture and Plant Growing, Almalybak, Kazakhstan \\ *e-mail: sybanbaeva_bota@mail.ru
}

\title{
Analysis of soybean world collection in conditions of south-eastern Kazakhstan
}

\begin{abstract}
The study of the phenotypic variability of the world crop collections in various conditions is an important step for identification of genetic factors (genes, quantitative trait loci), associated with yield and its components in order to increase the effectiveness of genetic and breeding programs. Current paper presents some results from the comparative analysis of the phenotypic data from the soybean world collection (originators - Kazakhstan, Russia, Canada, France, Sweden, Switzerland, Serbia, Belarus, Poland, Ukraine, Moldavia, Bulgaria, Belgium, Czech Republic, Slovakia, USA, China, Japan, Uzbekistan, Kyrgyzstan). The collection consisted of 192 cultivars and lines grown on the experimental plots of the Kazakh Research Institute of Agriculture and Plant Growing (KAZNIIZR, Almalybak v., Almaty region, Kazakhstan) in 2017 and 2018 yy. A number of key yield-associated traits, including plant height, pod insertion height, number of branches, nodules and seeds per plant, yield per plant and thousand seed weight were studied. It was noted that the yield over the two years of trials positively correlated with the abovementioned traits. The soybean accessions were ranked based on all the studied traits. As a result of the study of the yield components, several high-productive cultivars were identified. Cheremosh (Ukraine), Agassiz (USA), Iskra (Kazakhstan) and Evrika (Kazakhstan) showed high stable results in both years. The obtained results will be used in the genome-wide association study to identify the significant relations between DNA markers and complex quantitative traits to be applied in further genetic and breeding programs.
\end{abstract}

Key words: soybean, collection, cultivar, yield, correlation, economically valuable traits.

\section{Introduction}

Cultivated soybean (Glycine max (L.) Merrill) is an annual plant that belongs to the genus Soya (Glycine), family Fabaceae. Due to its rich biochemical composition, soybean is considered as a universal agricultural crop cultivated with the aim of producing food, technical raw materials and feed for livestock [1-3].

World soybean production over the past 10 years has increased by $65 \%$. According to the United States Department of Agriculture (USDA), in 2017 y., 346.9 million tons of soybeans were produced worldwide [4]. The main producers of soybeans are the United States, Argentina and Brazil, whose total output makes around $87 \%$ of the world production [5].

The lands under soybean in Kazakhstan increase from year to year. The total sowing area for this crop over the past 10 years has expanded to 129,000 in
2017, compared to 50,000 hectares in 2007. Soybean is grown mostly in Almaty, Kostanay and East Kazakhstan regions with about $83 \%$ of this crop grown in Almaty region [6].

The ecological trails of cultivars from different origins have an important role for modern agriculture. A wide range of soybean genotypes with studied traits in conditions of southeastern Kazakhstan is the basis of successful breeding programs. Nowadays more research is being conducted with the aim of upbringing early-maturing and high-protein soybean cultivars for cultivation in northern and eastern regions of the country $[7 ; 8]$.

For refinement of cultivars with high yield and quality, it is important to consider the variation and association of morphometric and productivity traits $[9 ; 10]$. In this regard, the actual aim of this work was to analyze the world soybean collection of local and foreign origins in the conditions of southeast Kazakhstan in 2017 and 2018. 


\section{Materials and methods}

The experimental material comprised 192 cultivars and lines from different countries of Eastern and Northern Europe (France, Sweden, Switzerland, Serbia, Russia, Belarus, Poland, Ukraine, Moldavia, Bulgaria, Belgium, Czech Republic and Slovakia), North America (Canada, USA), East Asia (China, Japan), Central Asia (Kazakhstan, Uzbekistan, Kyrgyzstan) was studied in conditions of southeast Kazakhstan in 2017 and 2018 [7; 11]. The cultivar (cv.) Zhansaya bred by the Kazakh Research Institute of Agriculture and Plant growing (KAZNIIZR) was involved into the study as a standard cv. for Almaty region [11].

Field experiments were conducted on experimental sites of KAZNIIZR, located at an altitude of 740 meters above the sea level, $43^{\circ} 15^{\prime} \mathrm{N}, 76^{\circ} 54^{\prime} \mathrm{W}$. This territory is characterized by the continental climatic conditions: mild and cool winters, cool spring, hot and dry summers, warm and dry fall. The soil cover is represented by light chestnut, loamy, or less often sandy soils [8].

The seeds of soybean accessions were sown in April of 2017 and 2018 according to Dospekhov [13], without any soil fertilizers. Structural anal- ysis was conducted using the guidelines of The State Commission for Variety Testing of agricultural crops [12]. Plants were selected to record the observations during the maturation period, prior to plots harvesting. For each accession the following traits were analyzed: Plant height $(\mathrm{PH}), \mathrm{cm}$; Pod insertion height $(\mathrm{PIH}), \mathrm{cm}$; Number of branches per plant (NBP); Number of nodules per plant (NNP), No.; Number of seeds per plant (NSP), No.; Yield per plant (YP); Thousand seeds weight (TSW), g [14].

Data processing was performed using Statistical Package for the Social Sciences (SPSS 16.0; https:// www.ibm.com/analytics/data-science/predictive-analytics/spss-statisticalsoftware).

\section{Results and discussion}

The world soybean collection grown in southeast Kazakhstan (KAZNIIZR) in 2017 and 2018, was analyzed by complex of morphometric and yield traits. Correlation analysis showed significant association between two years of field experience, with Pearson correlation coefficient $\mathrm{r}=0.34, \mathrm{P}<0.001$.

Table 1 represents data showing the variability ranges of the studied traits.

Table 1 - The variability ranges of morphometric and yield-associated traits

\begin{tabular}{|c|c|c|c|c|c|c|}
\hline \multirow{2}{*}{ Trait } & \multicolumn{3}{|c|}{2017} & \multicolumn{2}{c|}{2018} \\
\cline { 2 - 7 } & Min & Max & Mean & Min & Max & Mean \\
\hline PH & 22.7 & 132.6 & $75.8 \pm 2.1$ & 21.7 & 123.8 & $59.3 \pm 1.4$ \\
\hline PIH & 3.0 & 26.2 & $10.1 \pm 0.3$ & 2.5 & 14.4 & $6.7 \pm 0.2$ \\
\hline NBP & 0.0 & 3.1 & $1.4 \pm 0.0$ & 0.0 & 4.8 & $1.8 \pm 0.1$ \\
\hline NNP & 7.6 & 26.8 & $15.1 \pm 0.3$ & 6.9 & 40.0 & $17.4 \pm 0.4$ \\
\hline NSP & 1.5 & 103.6 & $35.2 \pm 0.9$ & 15.0 & 101.8 & $41.1 \pm 1.2$ \\
\hline YP & 2.5 & 19.3 & $10.6 \pm 0.3$ & 3.0 & 30.5 & $13.8 \pm 0.5$ \\
\hline TSW & 90.0 & 218.0 & $159.8 \pm 1.4$ & 124.0 & 268.0 & $179.0 \pm 1.7$ \\
\hline $\begin{array}{l}\text { Notes: PH - plant height, cm; PIH - pods insertion height, cm; NBP - number of branches per plant; NNP - number of nodules per } \\
\text { plant; NSP - number of seeds per plant; YP - seed yield per plant, g; TSW - thousand seed weight, g }\end{array}$ \\
\hline
\end{tabular}

Yield per plant (YP) is one of the key components of soybean productivity, which is dependent on the weather and/or agro ecological conditions ( $\sim 80 \%)$ and cultivar's genotype ( 20\%) [14]. In analyzed collection YP ranged as 2.5-19.3 g in 2017 and
3.0-30.5 $\mathrm{g}$ in 2018, with an average of 10.6 and 13.8 $\mathrm{g}$, respectively (Table 1). It was found that the yield of $54 \%$ of accessions was higher than in standard cv. Zhansaya in 2017 , while about $44 \%$ of the collection exceeded standard during the next year (Figure 1). 

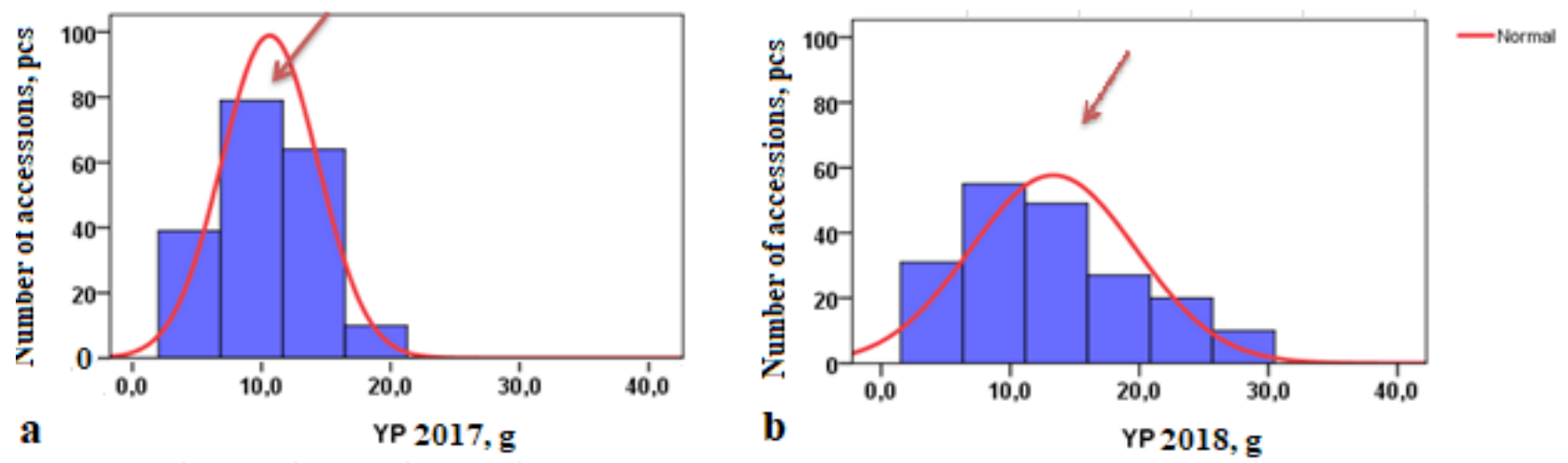

Figure 1 - Distribution of soybean world collection accessions by yield per plant in 2017 and 2018 yy. Note: YP - yield per plant. The arrow indicates the data for the standard cv. Zhansaya

Top ten soybean cultivars with the highest YP values observed in 2017 and 2018 in Almaty region are presented in Table 2. It was observed that cultivars Renta, Agassiz, Cheremosh, Iskra, Ana and Renta had a stable high YP in both years.

Correlation analysis illustrated that yield per plant had positive correlation with all studied traits, particularly with productivity components. Significant correlation with the highest coefficient between YP and the number of seeds per plant, NSP $(r=0.84$, $\mathrm{P}<0.001)$ and the number of nodules per plant, NNP $(r=0.79, \mathrm{P}<0.001)$ were found (Table 3$)$.

The number of seed per plant (NSP) is also a major component of productivity. This trait is directly related to the yield of soybean
[15]. In the first year of field trials, NSP varied from 10 to 103.6 seeds per plant (Table 1), for Zhansaya -35 seeds per plant, about $46 \%$ of the collection showed higher value than standard cv., and among them were Zispida 641 (Belgium) - 103.6, Slavia (Russia) - 93.7, Agassiz (USA) - 62.7, Misula (Kazakhstan) - 61 and Ana (Serbia) - 60 seeds per plant. In the second year, $30 \%$ of collections were higher than standard (47.9), including Vesta (Russia) 101.8, Agassiz (USA) - 96.0, Cheremosh (Ukraine) - 87.5, Vilana (Russia) - 80.2 and Bystritsa 2 (Russia) - 78.0 seeds per plant (Figure 2, a). It was noticed that cultivars Agassiz, Iskra, Zhalpaksai (Kazakhstan) and Vilana showed stable high NSP in both years.

Table 2 - Soybean cultivars with the top ten maximal ranks of yield per plant in 2017 and 2018

\begin{tabular}{|c|c|c|c|}
\hline Culivar name & YP, g (2017) & Culivar name & YP, $g(2018)$ \\
\hline Slavia (Russia) & 19.3 & Evrica (Kazakhstan) & 30.5 \\
\hline Agassiz (USA) & 19.1 & Vilana (Russia) & 30.0 \\
\hline Cheremosh (Ukraine) & 18.7 & Agassiz (USA) & 28.9 \\
\hline Misula (Kazakhstan) & 18.3 & Lira (Russia) & 28.7 \\
\hline Iskra (Kazakhstan) & 18.2 & Parkenta (Russia) & 28.5 \\
\hline Xinjiang D09-676 (China) & 17.9 & Xinjiang D10-130 (China) & 27.7 \\
\hline Ana (Serbia) & 17.5 & Vesta (Russia) & 27.6 \\
\hline Venera (Serbia) & 17.4 & Lybid (Ukraine) & 26.0 \\
\hline Renta (Russia) & 17.3 & Xinjiang D11-252 (China) & 26.0 \\
\hline Runo (Russia) & 17.3 & Standard cv. Zhansaya & 13.4 \\
\hline Standard cv. Zhansaya & 10.1 & & \\
\hline
\end{tabular}


Table 3 - Correlation links between key elements of yield structure

\begin{tabular}{|c|c|c|c|c|c|c|c|}
\hline Traits & PH & PIH & NBP & NNP & NSP & YP & TSW \\
\hline PH & 1 & & & & & & \\
\hline PIH & $0.63^{* * *}$ & 1 & & & & & \\
\hline NBP & $0.17^{* * *}$ & 0.09 & 1 & & & & \\
\hline NNP & $0.46^{* * *}$ & $0.17^{* * *}$ & $0.77^{* * *}$ & 1 & & & \\
\hline NSP & $0.52^{* * *}$ & $0.20^{* * *}$ & $0.59 * * *$ & $0.86^{* * *}$ & 1 & & \\
\hline YP & $0.45^{* * *}$ & $0.18^{* * *}$ & $0.48^{* * *}$ & $0.79 * * *$ & $0.84^{* * *}$ & 1 & \\
\hline TSW & $-0.18^{* * *}$ & $-0.15^{* * *}$ & 0.08 & 0.04 & -0.01 & $0.25^{* * *}$ & 1 \\
\hline
\end{tabular}

Notes: PH - plant height,cm; PIH - pods insertion height, cm; NBP - number of branches per plant, No.; NFN - number of nodules per plant, No.; NSP - number of seeds per plant, No.; YP - seed yield per plant, g; TSW - a thousand seeds weight, g; ${ }^{* * *}-\mathrm{P}<0.001$, $* *-\mathrm{P}<0.05, *-\mathrm{P}<0.01$
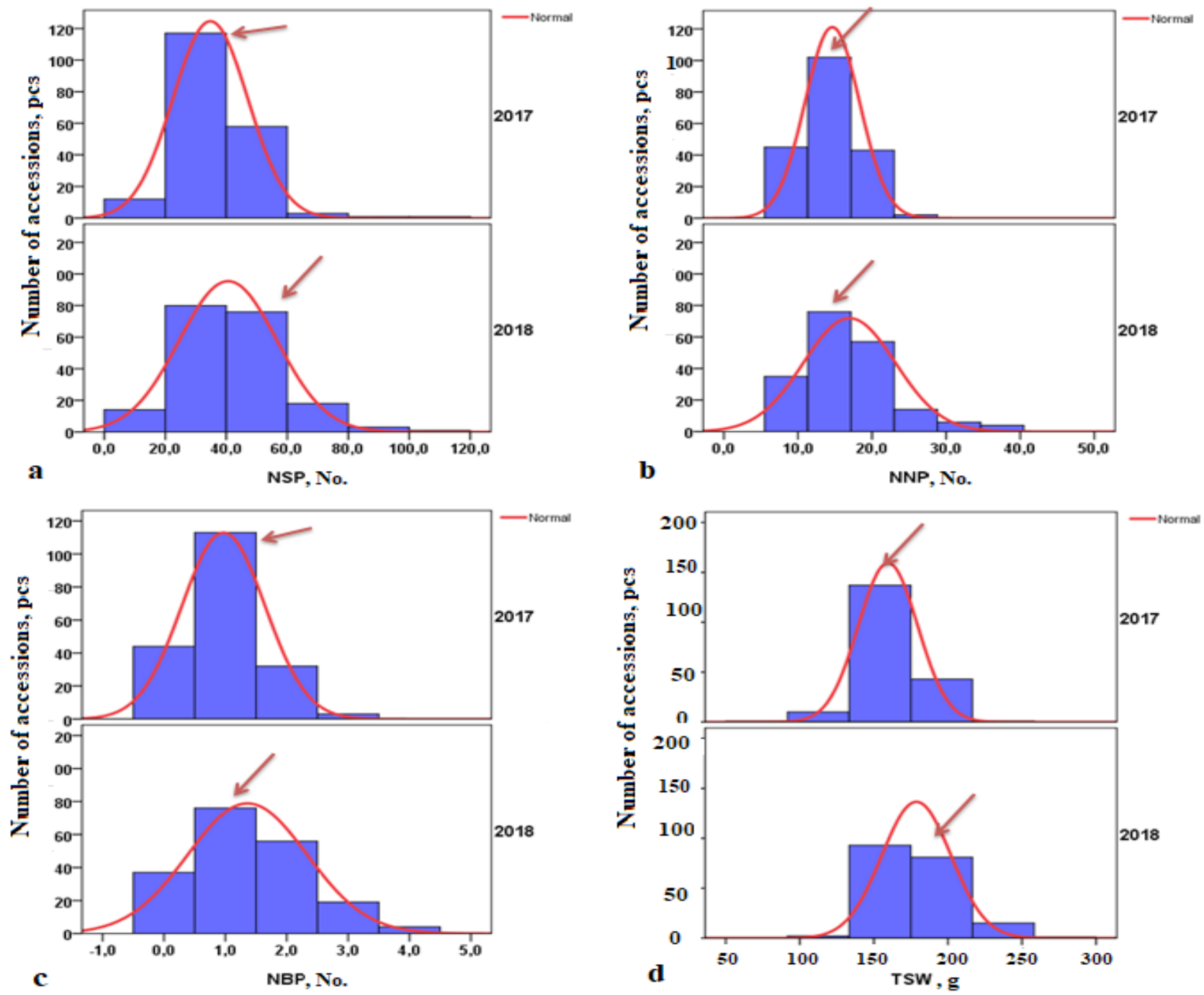

Figure 2 - Distribution of soybean accessions by number of seeds, nodules, and branches per plant and thousand seed weight in 2017 and 2018. Note: NSP - number of seeds per plant; NNP - number of nodules per plant;

NBP - number of branches per plant; TSW - thousand seed weight, g. The arrow indicates the data for the standard cv. Zhansaya 
The number of nodules per plant (NNP) correlated with all studied traits, except TSW (Table 3). It should be noted, that the NNP values range was higher in 2018 (from 6.9 to 40.0), than in the previous year $(7.6-26.0)$, respectively (Table 1, Figure $2, \mathrm{~b})$. The highest NNP values were observed for the following accessions: Evrika (Kazakhstan) - 26.0, Runo (Russia) - 26.8, 362/2 (Eastern Beauty) - 24.3, Niva 70 (Russia) - 23.1 and Misula (Kazakhstan) - 22.9 in 2017, and Agassiz (USA) - 40.0, Vesta (Russia) - 39.1, Cheremosh (Ukraine) - 36.4, Vilana (Russia) - 35.9 and Parker (USA) - 32.3 in 2018. In both years the stable high NNP showed cultivars Iskra, Cheremozh and Agassiz.

The number of branches per plant (NBP) is dependent on plant genotype and environment conditions. In our collection in the second year of field trails soybean plants NBP value increased to 4.5, comparing with 3.5 in 2017 (Figure 2, c). Some researchers, studying the number of branches, believe that the more branches on a plant, the more nodes and beans develop; therefore the higher the seed productivity is. Others consider that it is necessary to breed cultivars with a small number of branches - singlestem cultivars, the productivity of which is increased by rising of the plant density $[10 ; 16]$. The results of trails in Almaty region in both years showed that soybean plants with NBP more than one branch per plant had higher value of YP and it is similar to the first point of view. In addition, there was the high significant correlations between NBP and NNP $(\mathrm{r}=$ $0.77, \mathrm{P}<0.001)$, NBP and NSP $(\mathrm{r}=0.59, \mathrm{P}<0.001)$, and NBP with YP $(\mathrm{r}=0.48, \mathrm{P}<0.001)$ (Table 3$)$.

The thousand seed weight (TSW) is a very important trait of seed quality, which is dependent on the seed size and fullment. According to the literature, in conditions of water deficiency, genotypes with larger seeds have advantage in high yield production due to their better absorbing ability $[15 ; 17]$. In analyzed collection TSW varied from 90.0 to $218.0 \mathrm{~g}$ in 2017 , and from 124.0 to $268.0 \mathrm{~g}$ in 2018 (Table 1). TSW in the first year of field experiments were recorded for Xinjiang a don 1 (China) - 218 g, Soer 345 (Russia) $-211.3 \mathrm{~g}$ and Agassiz (USA) $-208 \mathrm{~g}$, in the second year - Almaty (Kazakhstan) - 268 g, Nikko (Serbia) $-255 \mathrm{~g}$ and Lambert (USA) $-239.5 \mathrm{~g}$. More than half of the collection exceeded the results of Zhansaya (148.7 and $173 \mathrm{~g}$ in 2017 and 2018, respectively) (Figure 2, d).

Correlation analysis of TSW indicated negative correlation with $\mathrm{PH} . \mathrm{r}=-0.18, \mathrm{P}<0.001)$ and the pod insertion height, PIH, $(\mathrm{r}=-0.15(\mathrm{P}<0.001)$. On the other hand, there was a positive correlation with the yield per plant, $\mathrm{r}=0.25(\mathrm{P}<0.001)$. In addition, correlation was found neither between TSW and NLB, nor TSW and NFN (Table 3).

Plant height $(\mathrm{PH})$ is a major morphometric trait in breeding practice as it linked to the soybean lodging score [18]. PH in analysed accessions varied from 22.7 to $132.6 \mathrm{~cm}$ in 2017 and from 21.7 to $123.8 \mathrm{~cm}$ in the next year with an average equal to $75.8 \pm 2.1$ and $59.3 \pm 1.4$, respectively (Table 1 ). The standard $\mathrm{cv}$. Zhansaya also showed the tendency of the stem shortening in second year in comparison with the 2017 (99.6 in 2017 vs $77.1 \mathrm{~cm}$ in 2018). Determinant, indeterminate and semideterminate types of soybean plant habitat were observed. As it is shown in Fig.3, in 2018 almost the entire soybean collection showed average or short $\mathrm{PH}$, compared with data of 2018 (Figure 3, a).

Another morphometric characteristic used in the field trials was the pod insertion height (PIH). This trait plays an important role in the harvesting period. The higher the first pod insertion, the less likely the soybean stem is to break. Plants with especially low insertion of pod led to loses of seed at harvest. PIH varies from environmental conditions $[19 ; 20]$.

The standard $\mathrm{cv}$. Zhansaya showed PIH of $13.5 \mathrm{~cm}$ and $9.1 \mathrm{~cm}$ in 2017 and 2018, respectively. Just $21 \%$ and $9.1 \%$ of the soybean collection showed higher values than Zhansaya (Figure 3, b). PIH had positive and significant correlation with $\mathrm{PH}, \mathrm{r}=0.63(\mathrm{P}<0.001)$ and negative correlation with TSW, $\mathrm{r}=-0.18(\mathrm{P}<0.001)$ (Table 3$)$.

ANOVA analysis (analysis of variance) made it possible to identify significant affect of environmental conditions to all studied traits of soybean collection, with the highest effect on PIH (84.19\%), then on TSW (74.62\%), PH (41.71\%) and YP (34.36\%) (Table 4).

It is clear that the weather and growing conditions affect to the grain yield. According to the literature, even with the great combination of genetic resources and agronomic factors, the environmental stresses like high temperature, humidity, salinity and so on, can sharply decrease soybean yield. The stresses negatively effect on the cellular function of plant and its metabolic activity [21]. The soybean varieties and lines harvested in Almaty region in 2018 showed higher results for major productivity components (YP, NSP, NNP, TSW) comparing with 2017, which might be consequented with better environmental conditions during soybean maturation stage in 2018 (Figures 1-3). 

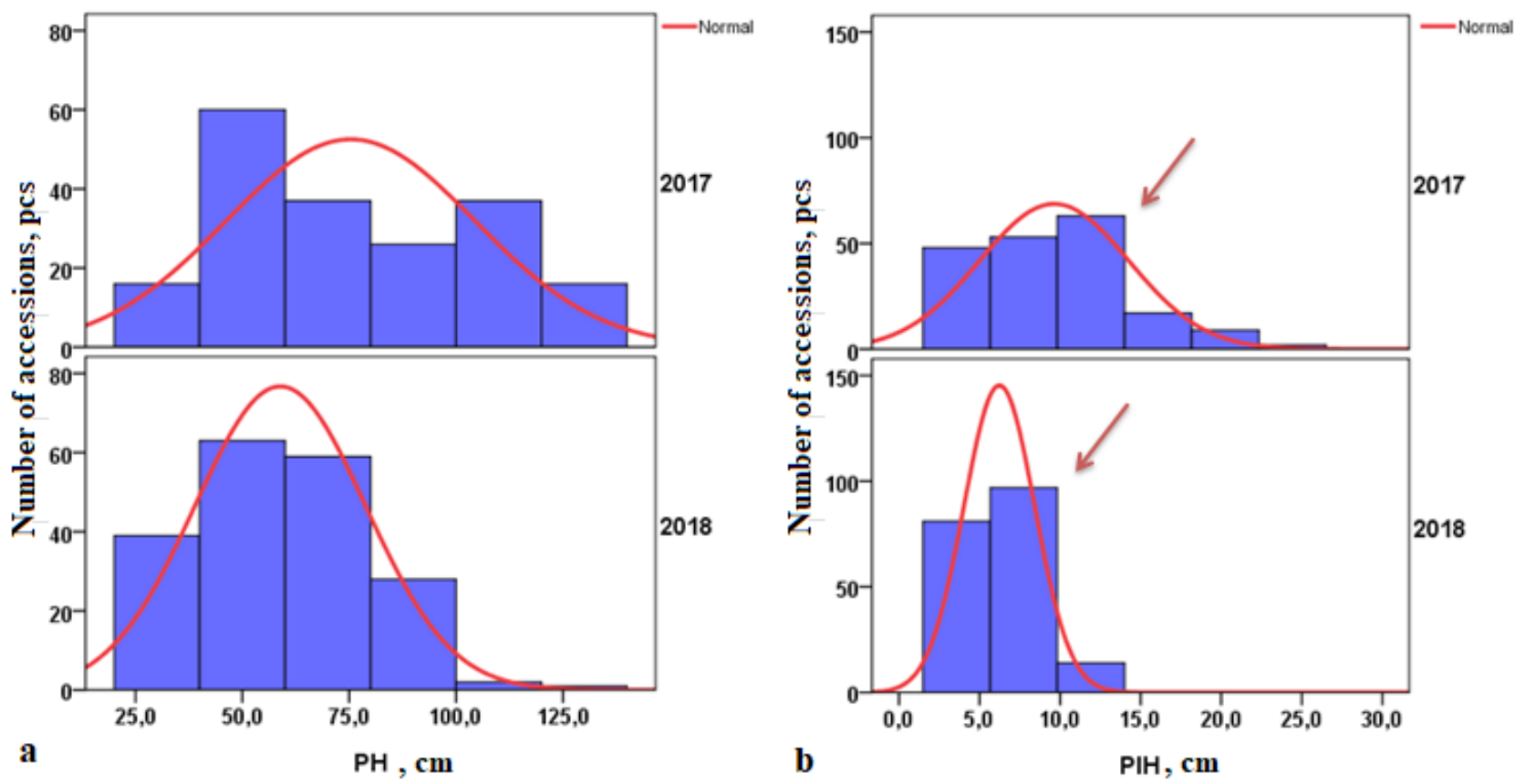

Figure 3 - Distribution of soybean collection by plant height and pod insertion height in 2017, 2018 yy. Note: PH - plant height, PIH - pod insertion height.

The arrow indicates the data for the standard cv. Zhansaya

Table 4 - Analysis of variance by one factor

\begin{tabular}{|l|c|c|c|}
\hline \multicolumn{1}{|c|}{ Traits } & df & Mean square & $\mathrm{F}$ \\
\hline Plant height (PH), cm & 383 & 26053.5 & $41.71^{* * *}$ \\
\hline Pods insertion height (PIH), cm & 383 & 1110.4 & $84.19^{* * *}$ \\
\hline Number of branches per plant (NBP) & 383 & 14.6 & $20.88^{* * *}$ \\
\hline Number of nodules per plant (NNP) & 383 & 511.0 & $19.57^{* * *}$ \\
\hline Number of seeds per plant (NSP) & 383 & 3243.3 & $15.87^{* * *}$ \\
\hline Seed yield per plant (YP), g & 383 & 943.7 & $34.36^{* * *}$ \\
\hline Thousand seed weight (TSW), g & 383 & 35305.0 & $74.62^{* * *}$ \\
\hline Note: $* * *-\mathrm{P}<0.001$ & & & \\
\hline
\end{tabular}

Therefore, the world collection of soybean cultivars and lines from Eastern and Northern Europe (France, Sweden, Switzerland, Serbia, Belarus, Poland, Ukraine, Moldavia, Bulgaria, Belgium, Czech Republic, Slovakia), North America (Canada, USA), East Asia (China, Japan), Central Asia (Kazakhstan, Uzbekistan, Kyrgyzstan) countries were tested in Almaty region.

The collection was ranged based on seven yieldassociated traits. More valuable highly productive genotypes were revealed. The obtained data may be Int. j. biol. chem. (Online) used in genome-wide association studies and soybean breeding programs.

\section{Conclusion}

The world soybean collection consisted of 192 cultivars and lines both local and foreign breeding were evaluated in the field conditions of southeast Kazakhstan in 2017 and 2018. It was determined that the yield per plant had positive correlation with all studied traits, particularly with productivity compo- 
nents. Significant association with the highest coefficient were found between traits YP - NSP $(r=0.84$, $\mathrm{P}<0.001)$ and $\mathrm{YP}-\mathrm{NNP}(\mathrm{r}=0.79, \mathrm{P}<0.001)$. Over a two years period Cheremosh (Ukraine), Agassiz (USA) and Iskra (Kazakhstan) showed the maximum values for three most important yield traits - yield per plant, number of seeds and nodules per plant. In addition, it was revealed that Kazakh cv. Evrika prevailed on NFN and NLB in both years; while in 2018 it was one of the best on YP. In total, 10 soybean accessions were determined as high-productivity and valuable cultivars for breeding programs.

Obtained results on the phenotypical and productivity traits variability of the world soybean collection will be used in the future genome-wide associations studies in order to identify marker-trait associations and search for reliable links between DNA markers and quantitative traits.

\section{Acknowledgement}

This study was conducted within the framework of the project AP05131592 "Genome-wide associations study of resistance to fungal diseases of soybean in Kazakhstan" supported by the Ministry of Education and Science of the Republic of Kazakhstan for 2018-2020 yy.

\section{References}

1. Zelencov S.V. (2006) Sovremennoe sostojanie sistematiki kul'turnoj soi Glycine max (L.) Merrill [The current state of systematic soybean taxonomy Glycine max (L.) Merrill]. Scientific and technical bulletin VNIIMK, vol. 1, no. 134, pp. 3448.

2. Boiko A.T., Karyagin Y.G. (2004) Soja vysokobelkovaja kul'tura [Soybean high protein culture]. Almaty, $22 \mathrm{p}$.

3. Chen K.I., Erh M.H., Su N.W., Liu W.H., Chou C.C., Cheng K.C. (2012) Soyfoods and soybean products: from traditional use to modern applications. Appl Microbiol Biotechnol., vol. 96, no. 1, pp. 9-22.

4. Agricultural Market Information System (2019) Market Monitor., no. 66, p. 18.

5. Masuda T., Goldsmith P.D. (2009) World soybean production: area harvested, yield, and longterm projections. IFARM, vol. 12, no. 4, pp. 1-31.

6. Kazahstan ezhegodno narashhivaet ploshhadi posevov soi [online resourse]; https://kapital.

Int. j. biol. chem. (Online) kz/economic/70818/kazahstan-ezhegodno-naracshivaet-plocshadi-posevov-soi.html (accessed 20.02.2019).

7. Didorenko S.V., Kudaybergenov M.S., Abugalieva S.I., Turuspekov E.K. Priznaki produktivnosti sortoobraztsov skorospeloy kollektsii soi (Glycine max) v usloviyah yugo-vostochnogo Kazahstana. $\mathrm{XX}^{\text {th }}$ scientific practice conference proceedings, pp. 122-124.

8. Abugalieva S., Didorenko S., Anuarbek S., Volkova L., Gerasimova Y., Sidorik I., Turuspekov Y. (2016) Assesment of soybean flowering and seed maturation time in different latitude regions of Kazakhstan. Public library of science, vol. 11, pp. $1-12$.

9. Didorenko S.V. (2014) Dostizheniya selekcionnyh rabot po soe $\mathrm{v}$ Kazahstane [Achievements of breeding works on soybeans in Kazakhstan]. News of NAS RK, Agricultural series, vol. 1, pp. 22-27.

10. Trunov M.V. (2017) Model' rannespelogo sorta soi dlja Juzhno-evropejskoj chasti Rossii [Model of early ripe soybean variety for the South European part of Russia]. Scientific and technical bulletin VNIIMK, vol. 2, no. 170, pp. 27-36.

11. Zatybekov A., Abugalieva S., Didorenko S., Rsaliyev A., Turuspekov Y. (2018) GWAS of a soybean breeding collection from South East and South Kazakhstan for resistance to fungal diseases. Vavilov Journal of Genetics and Breeding, vol. 22, no. 5, pp. 536-543.

12. Dospehov B.A. (1979) Metodika polevogo opyta [Methods of field experiments]. M.: Kolos, $416 \mathrm{p}$.

13. Kuyshenov M.M. (2014) KR Memlekettik reestr. Forma plyus, $145 \mathrm{p}$.

14. Korsakov N.I., Makashewa R.H., Adamova O.P. (1968) Metodika izuchenija kollekcii zernobobovyh kul'tur [Methods of studying the collection of leguminous crops]. L.: VIR, $175 \mathrm{p}$.

15. Mesfin, H. Habtegebriel (2018). Path analysis, genetic variability and correlation studies for soybean (Glycine max (L.) Merill) for grain yield and secondary traits at Asosa, Western Ethiopia. Greener Journal of Plant Breeding and Crop Science, vol. 6, no. 3, pp. 35-46.

16. Agudamua , T. Yoshihira, T. Shiraiwa. (2016) Branch development responses to planting density and yield stability in soybean cultivars. Plant Prod Sci., vol. 19, no. 3, pp. 331-339.

17. Deivasigamani S., Swaminathan C. (2018) Evaluation of seed test weight on major field crops. 
International journal of research studies in agricultural sciences, vol. 4, pp. 8-11.

18. Wilcox J. R., Sediyama T. (1981) Interrelationships among height, lodging and yield in determinate and indeterminate soybeans. Euphytica, vol. 30, no. 2, pp. 323-326.

19. Didorenko S.V., Abugalieva S.I., Zatybekov A.K. Gerasimova E.G., Sidorik I.V., Turuspekov E.K. Izuchenie skorospeloj kollekcii soi v uslovijah severnogo, vostochnogo i jugovostochnogo Kazahstana [Study of the earlyripening soybean collection in the conditions of northern, eastern and southeastern Kazakhstan].
Research and results, KazNAU, vol. 4, no. 76, pp. 294-303.

20. Galeev R.R., Vyshegurov S.K., Samarin I.S., Demshina V.S., Gumel M.A. (2018) Yield Capacity and Grain Quality of Soybeans Depending on Agrotechnical Cultivation Methods. Journal of Pharmaceutical Sciences and Research, vol. 10, no. 7, pp. 1668-1671.

21. Hasanuzzaman M., Nahar K., Rahman, A., Jubayer Al M., Shahadat H.Md., Masayuki F. (2016) Soybean Production and Environmental Stresses. pp. 61-102. In: Environmental stresses in soybean production. Academic Press, vol. 2. 